Т.М. АРТЮХ, Н.П. ШАПОВАЛОВА, А.В. НЕКРАСОВА Національний університет харчових технологій

\title{
ОЦІНКА ЯКОСТІ ГУБНИХ ПОМАД НА РИНКУ УКРАЇНИ
}

\author{
Т.Н. АРТЮХ, Н.П. ШАПОВАЛОВА, А.В. НЕКРАСОВА \\ Национальный университет пищевых технологий
}

\author{
ОЦЕНКА КАЧЕСТВА ГУБНЫХ ПОМАД НА РЫНКЕ УКРАИНЫ \\ T.N. ARTYUKH, N.P. SCHAPOVALOVA, A.V. NEKRASOVA \\ National University of Food Technology
}

\section{EVALUATION OF QUALITY OF LIPSTICK ON THE MARKET OF UKRAINE}

\section{https://doi.org/10.36910/6775-2310-5283-2018-11-06}

Мета. Оиінка якості та безпечності косметичних засобів, зокрема губних помад для розробки практичних рекомендацій щодо удосконалення системи технічного регулювання та ринкового нагляду за парфумерно-косметичними товарами, розробка практичних рекомендачій щооо свідомого вибору косметичної продукиї та захисту споживачів.

Методика. При дослідженнях використовували передбачені діючими держсавними стандартами методи, які дозволяють встановити якість губних помад, зокрема органолептичні, фізико-хімічні та мікробіологічні показники.

Результати. Встановлено, щзо значна частка досліджуваних губних помад, щзо реалізується на ринку України, не відповідає нормам ГОСТ 28767-90, ГОСТ 28303 - 89 за органолептичними, фізико-хімічними та мікробіологічними показниками, не відповідає Державним санітарним правилам і нормам безпеки продукиї парфумерно-косметичної промисловості.

Наукова новизна. Запропоновано, розроблено, апробовано новий методологічний підхід до експертної оцінки якості, безпечності та конкурентоспроможності косметичних товарів (на прикладі губних помад).

Практична значимість. Запропоновано методику з оцінювання якості та безпечності косметичних товарів, зокрема губних помад, $з$ метою прийняття управлінських рімень щзодо товаропостачання роздрібних торговельних підприємств.

Ключові слова: косметика, губна помада, якість, безпечність, дослідження, стандарти, норми.

Постановка проблеми у загальному вигляді та іï зв'язок із важливими науковими чи практичними завданнями. Губна помада $\epsilon$ найпоширенішим засобом декоративної косметики, яка призначена для 
фарбування губ і захисту їх від сухості та несприятливої дії довкілля. Частка губних помад у загальному асортименті косметичних товарів на ринку України складає 30\%, серед яких великий вибір помад різноманітних текстур, кольорів і відтінків різного функціонального призначення, але їх якість та безпечність залишається під сумнівом. До складу губних помад можуть входити шкідливі хімічні сполуки і ніхто не застрахований від споживання неякісного продукту. Небезпечними для здоров'я можуть бути інгредієнти, що входять до складу помади або потрапляють туди шляхом заміни якісних складових: нафтопродукти (мінеральні масла, кристалічні парафіни i мікрокристалічний віск) мають здатність накопичуватися в нирках, печінці і лімфатичних вузлах; агресивні хімічні барвники (фарбувальні пігменти червоного відтінку, що отримують 3 кам'яновугільної смоли - токсичні речовини, які викликають подразнення шкіри, нудоту, головний біль); ароматизатори -викликають сухість і розтріскування шкіри губ; свинець, який поряд з ртуттю і миш'яком, є найбільш токсичним хімічним елементом, що негативно впливає на нервову систему та знижує розумову діяльність; тверді парафіни, які руйнують зуби.

Встановлено, що жінка за все своє життя з'їдає близько 4,5 кілограм помади, а чоловіки - приблизно 1,5 кілограм. Тому принципово важливо, щоб помада була якісною та безпечною, без шкідливих компонентів.

Аналіз останніх досліджень, у яких започатковано вирішення проблеми. Теоретичною основою оцінювання якості та безпечності косметичної продукції стали публікації провідних науковців України Калинюк Т. Г., Білоус С. Б., Росії: Вілкової С.А. Войткевич С.А., Луценко Н.Г., Авдеевої В., Асанової Н.А. Александрової Г.А., Озерскої О.С. та ін. Серед іноземних авторів можна виділити праці Yrina Begon, Maeda T., Okada M., Hara T. та ін [1-6].

Проте в зазначених роботах не приділено належної уваги аналізу фактичних показників безпечності та якості косметичної продукції, що реалізується на ринку України як вітчизняного, так і закордонного виробника, а також стану гармонізації національних стандартів до європейських щодо косметичної продукції.

Цілі статті. Оцінка якості та безпечності косметичних засобів, зокрема губних помад для розробки практичних рекомендацій щодо удосконалення системи технічного регулювання та ринкового нагляду за парфумернокосметичними товарами, розробка практичних рекомендацій щодо свідомого вибору косметичної продукції та захисту споживачів. 
Об’скт дослідження. Губні помади, що реалізуються на ринку України: п’ять губних помад таких марок: «Christian Dior» -1, «Max Factor»-2, «Bourjois»-3, «YVES ROCHER»-4, «ESSENCE»-5, «L'Oreal Intensely Moisturizing Lipcolor - Heroic»-6.

Методи дослідження. Для визначення якості помад було використано стандартні органолептичні та лабораторні методи дослідження: краплепадіння помад - за ГОСТ 29188.1-91; кислотне та карбонільне число за ГОСТ29188.291; мікробіологічні тести за Державними санітарними правилами; органолептичні дослідження за ГОСТ 28767-90 [7-10].

\section{Виклад основного матеріалу дослідження 3 повним обгрунтуванням} отриманих наукових результатів. Відповідно до міжнародного стандарту ДСТУ ISO 9000:2007, якість - ступінь, до якого сукупність власних характеристик задовольняє вимоги. Тому, для оцінки якості було досліджено основні показники за стандартом, вимогами на безпечність та оцінено їх відповідно до споживчих переваг за оцінкою конкурентоспроможності. Результати дослідження власних фізико-хімічних показників губних помад представлено у табл. 1 та 2.

Таблиця 1

\section{Результати дослідження фізико-хімічних показників губних помад}

\begin{tabular}{|l|c|c|c|c|c|c|c|}
\hline \multicolumn{1}{|c|}{\begin{tabular}{l} 
Показники \\
\multicolumn{1}{|c|}{ якості }
\end{tabular}} & $\begin{array}{c}\text { за ГОСТ } \\
28767-90\end{array}$ & \multicolumn{6}{|c|}{ Дослідні зразки } \\
\cline { 5 - 9 } & №1 & №2 & №3 & №4 & №5 & №6 \\
\hline $\begin{array}{l}\text { Температура } \\
\text { краплепадіння }\end{array}{ }^{\circ} \mathrm{C}$ & 58 & 65 & 70 & 60 & 72 & 78 \\
\hline $\begin{array}{l}\text { Кислотне число, мг } \\
\text { КОН/г }\end{array}$ & не більше 15 & 9 & 10 & 11 & 9 & 11 & 19 \\
\hline $\begin{array}{l}\text { Карбонільне число, } \\
\text { мг КОН/г }\end{array}$ & не більше 8 & 3 & 5 & 4 & 4 & 3 & 9 \\
\hline
\end{tabular}

Температура краплепадіння для губних помад має знаходитися у межах 55-80 C. Встановлено, що помади Christian Dior, YVES ROCHER та Max Factor мають найнижчу температуру краплепадіння. Це вказує на те, що до їх складу входить натуральний віск. До складу помад Christian Dior та YVES ROCHER входить канделільський віск (це рослинний віск, він виробляється 3 певних різновидів кактусів). Канделільський віск блискучий, твердий, з високою точкою плавлення $-70^{\circ} \mathrm{C}$ та високою гелеутворюючою активністю. В косметичних рецептурах поліпшує абсорбцію масел, однорідність продукту, блиск, виступає емолентом та пленкоутворювачем. Може легко емульгуватися, має легкий приємний запах. Помада Max Factor 
має у своєму складі Карнаубський віск (це віск бразильської пальми). Карнаубський віск (віск пальмовий) - довговічний, він не прогіркає і навіть роки потому не псується, він гіпоалергений, попереджає зневоднення шкіри. У складі косметичного засобу, як правило не написано що це «карнаубський віск», скоріше там буде: copernicia cerifera або carnauba wax. До складу помад марок Bourjois, ESSENCE та L'Oreal входить штучний віск, тому температура краплепадіння $\epsilon$ вищою. Кислотне та карбонільне число усіх досліджуваних зразків, крім помади L'Oreal, у нормі. Шостий зразок (L'Oreal Intensely Moisturizing Lipcolor - Heroic) перевищує усі нормовані показники якості і $€$ небезпечним для здоров'я. При визначенні мікробіологічних показників, уся косметика поділяється на три групи: косметика в ампулах; дитяча косметика, косметика навколо очей; решта косметики. Мікробна забрудненість косметичних виробів оцінюється кількістю колонієутворювальних одиниць (КУО) в 1 г або $1 \mathrm{~cm}^{3}$ продукції. Косметика в ампулах повинна бути стерильною. Для дитячої групи допускається вміст мезофільних бактерій не більше ніж 102 КУО. Для решти косметики - не більше 103 КУО. Дріжджів і пліснявих грибів - не більше ніж 102 КУО. Наявність у косметичних засобах патогенних стафілококів та інших бактерій недопустима. Результати мікробіологічних досліджень наведено у табл. 2.

Таблиця 2

\section{Результати дослідження мікробіологічних показників та показників безпечності губних помад}

\begin{tabular}{|c|c|c|c|c|c|c|c|}
\hline \multirow{2}{*}{$\begin{array}{c}\text { Показники } \\
\text { якості }\end{array}$} & \multirow[t]{2}{*}{ Норма } & \multicolumn{6}{|c|}{ Дослідні зразки } \\
\hline & & №1 & №2 & №3 & №4 & №5 & №6 \\
\hline $\begin{array}{l}\text { Кількість мезофільних аеробних та } \\
\text { факультативно-анаеробних } \\
\text { мікроорганізмів, КУО/г(куб.см) }\end{array}$ & $<100$ & 45 & 65 & 87 & 63 & 81 & 102 \\
\hline $\begin{array}{l}\text { Бактерії } \quad \text { сем. } \quad \text { Entero-bacter } \\
\text { eaceae } 1 \text { г (куб.см) продукції }\end{array}$ & Відсутні & - & - & - & - & - & - \\
\hline $\begin{array}{l}\text { Staphylococ-cusaureus в } 1 \text { г (куб.см) } \\
\text { продукції }\end{array}$ & Відсутні & - & - & - & - & - & - \\
\hline $\begin{array}{ll}\text { Pseudomonas } & \text { aeruginosa } \\
1 \text { г (куб.см) продукції } & \end{array}$ & Відсутні & - & - & - & - & - & - \\
\hline
\end{tabular}

Аналіз даних табл. 2 вказує на те, що мікробіологічні показники усіх досліджуваних зразків, крім 6, відповідають Державним санітарним правилам i нормам безпечності продукції парфумерно-косметичної промисловості. 
Дослідження вказують на те, що 5 зразків придатні для подальшого порівняння та оцінки конкурентоспроможності.

Оцінка конкурентоспроможності губних помад здійснювалась методом «рангової кореляції» за номенклатурою показників, котра була обговорена та проранжована експертами та пробантами. Було визначено коефіцієнти вагомості важливих критеріїв конкурентоспроможності: покривна здатність; консистенція; стійкість кольору; зручність у використанні; безпечність; запах; механізм подачі олівця губної помади; відповідність кольору зазначеному на маркуванні; зовнішній вигляд (однорідне гладке забарвлення, оригінальність дизайну туби); бренд (виробник).

Найважливішими показниками споживних властивостей губних помад визначено: покривну здатність; консистенцію; безпечність; зручність у використанні. Конкурентоспроможними є зразки губної помади «Christian Dior» та «Max Factor», оскільки саме ці зразки отримали найкращі результати.

Ці помади мають приємний запах, зручну форму, залишають приємне відчуття на шкірі протягом дня, є небезпечними та якісними. Дані зразки характеризуються привабливим дизайном упаковки, високим іміджом товаровиробника при досить помірній ціні.

Висновки та перспективи подальших досліджень. Результати досліджень встановили, що вказані технічні показники за нормативною документацією характеризують затверджену рецептуру та не являються показниками споживних властивостей. Таким чином показано необхідність оцінки якості косметичних товарів методом практичних випробувань в сполученні з експертними в частині визначення номенклатури показників, коефіцієнтів вагомості, а також визначення значень показників. Розроблена методологічна основа експертної оцінки якості та безпечності губних помад 3 використанням аналізу та систематизації знань, нормативно-правової бази та практичного досвіду. Вдосконалена методика оптимізації номенклатури показників якості та безпечності, що базується на застосуванні думок експертів та пробантів.

Для подальшого розвитку та захисту ринку парфумерно-косметичних товарів від підробок в Україні слід впроваджувати у систему технічного регулювання Проект технічного регламенту щодо косметичної продукції 3 метою актуалізації системи контролю якості, безпечності, маркування, упакування у акредитованих НААУ випробувальних лабораторіях. 


\section{Література}

1. Вилкова С.А. Оценка безопасности и качества парфюмерно-косметической продукции // Партнеры и конкуренты. - 2003. - №4. - С.34 - 39.

2. Войткевич С.А. Эфирные масла, ароматизаторы, консерванты. Ограничения при использовании. - М.: Пищевая промишленность, 2000. - 96 с.

3. Yrina Begon. Как создать натуральный косметический продукт // Сырье и упаковка. - 2002. - №2. - С.28-29.

4. Луценко Н.Г. Консерванты в косметике: биохимический аспект // Сырье и упаковка. - 2001. - №8. - С.22-24.

5. Авдеева.В. Основные параметры контроля качества готового косметического продукта с точки зрения микробной чистоты // Сырье и упаковка. - 2001. - №8. - С.26-27.

6. Асанова Н.А. Александрова Г.А. Микробиологическая защита косметических средств // Бытовая химия. - 2002. - №3. - С.26-34.

7. Про забезпечення санітарного та епідемічного благополуччя населення: Закон України від 24.02.1994 року // Відомості Верховної Ради України. - 1994. - № 27. - Ст. 218

8. ГОСТ 28767-90 «Изделия декоративной косметики на жировой основе. Общие технические условия». - М.: Издательство стандартов, 1991. - 10с.

9. ГОСТ 29188.1-91 «Методы определения температуры каплепадения». - М.: ИПК Издательство стандартов, 1991 - 4c.

10. ГОСТ 29188.2-91 «Изделия косметические. Метод определения водородного показателя, $\mathrm{pH»-} \mathrm{М.:} \mathrm{ИПК} \mathrm{Издательство} \mathrm{стандартов,} 1992-4$ с.

Цель. Оченка качества и безопасности косметических средств, в частности губных помад для разработки практических рекомендаций по совершенствованию системы технического регулирования и рыночного надзора за парфюмернокосметическими товарами, разработка практических рекомендаций по сознательному выбору косметической продукции и защиты потребителей.

Методика. При исследованиях использовали предусмотренные действующими государственными стандартами методы, которые позволяют установить качество губных помад, в частности органолептические, физико-химические и микробиологические показатели губных помад.

Результаты. Установлено, что не все исследуемые помады соответствуют нормам, прописанным в ГОСТ 28767-90 и ГОСТ 28303 - 89 по органолептическим, физикохимическим и микробиологическим показателям и не соответствуют Государственным санитарным правилам и нормам безопасности продукиии парфюмерно-косметической промышленности.

Научная новизна. Предложено, разработано, апробировано новый методологический подход $к$ экспертной оценки качества, безопасности и конкурентоспособности косметических товаров (на примере губных помад).

Практическая значимость. Предложена методика по оценке качества $и$ безопасности косметических товаров, в частности помад, с целью принятия управленческих решений по товароснабжению розничных торговых предприятий. 
Ключевые слова: косметика, помада, качество, безопасность, исследования, стандартыл, нормы.

Purpose. Assessing the quality and safety of cosmetics, including lipsticks, for developing practical recommendations for improving the system of technical regulation and market surveillance of perfumery and cosmetics, developing practical recommendations for conscious choice of cosmetic products and consumer protection.

Methodology. In the studies, methods used to determine the quality of lipstick, in particular, organoleptic, physico-chemical and microbiological indicators of lipsticks, were used by the applicable state standards.

Findings. It has been established that not all lashings under study comply with the norms prescribed in GOST 28767-90 and GOST 28303 - 89 for organoleptic, physico-chemical and microbiological parameters and don't conform to the State Sanitary Rules and Safety Standards for the perfumery and cosmetics industry.

Originality. Proposed, worked out, the new methodological approach to expert quality assessment, safety and competitiveness of cosmetic commodities (on the example of lipsticks).

The practical value. The technique for assessing the quality and safety of cosmetic products, in particular lipstick, is proposed for the purpose of making managerial decisions on the supply of goods for retail trade enterprises.

Key words: cosmetics, lipstick, quality, safety, research, standards, norms.

Рекомендовано до публікації докт.техн.наук. професором Луцького НТУ Байдаковою Л.І. Стаття надійшла в редакиію 05.03.2018 p. 